Lauro Miranda Demenech ${ }^{1,2}$

(- https://orcid org/0000-0002-7285-2566

Samuel C. Dumith1,3

Ohttps://orid. org/0000-0002-5994-735X

Alessandro S. Dytz²

O- https://orcid.org/0000-0002-3788-516X

Fernanda Fontes ${ }^{2}$

Ohttps://orcid.org/0000-0002-3641-549x

Lucas Neiva-Silva 2,3,4

(2) htpps://orcid.org/0000-0002-7526-2238

\section{Under pressure: non-medical use of prescription drugs among undergraduate students}

\author{
Sob pressão: uso não médico de medicamento \\ prescrito entre estudantes de graduação
}

DOI: $10.1590 / 0047-2085000000260$

\begin{abstract}
Objective: To measure lifetime, last-year and last-month prevalence of Non-Medical Use of Prescription Drugs (NMUPD) as well as the characteristics associated to last-month NMUPD among undergraduate students of a university in southern Brazil. Methods: This was a cross-sectional study, with a sample that was selected through a clustered systematic sampling strategy. Multivariate analysis was conducted with Poisson regression according to a four-level hierarchical model of analysis. Fieldwork was conducted in 2015, and 1,423 students participated. Results: Lifetime, last-year and last-month prevalence of NMUPD were $25.2 \%, 13.1 \%$ and $8.5 \%$, respectively. Anxiolytics and barbiturates were the most prevalent. Variables independently associated were being female, having a family income lower than one or higher than six Brazilian minimum wages, being enrolled in a health sciencesrelated undergraduate course, and having reported lifetime NMUPD by a friend. Conclusions: Based on these results, we suggest the development of prevention and promotion activities on this theme for students and professors, especially among those from health sciences-related courses. These interventions should focus on harmful effects of NMUPD, psychosocial coping strategies and socially established gender roles.
\end{abstract}

\section{KEYWORDS}

Non-medical use of prescription drugs, universities, students.

\section{RESUMO}

Objetivo: Medir a prevalência do Uso Não Médico de Medicamento Prescrito (UNMMP) na vida, no último ano e no último mês, bem como as características associadas ao UNMMP no último mês entre estudantes de graduação de uma universidade no sul do Brasil. Métodos: $O$ estudo teve delineamento transversal com amostragem aleatória sistemática por conglomerados. A análise multivariável foi conduzida por meio de regressão de Poisson com ajuste robusto da variância seguindo um modelo hierárquico de análise de quatro níveis. O estudo foi conduzido em 2015 e 1.423 estudantes participaram. Resultados: As prevalências de UNMMP na vida, no último ano e no último mês foram de 25,2\%, $13,1 \%$ e $8,5 \%$, respectivamente. Ansiolíticos e barbitúricos foram os mais prevalentes. As variáveis associadas foram ser do sexo feminino, ter uma renda família menor que um ou maior que seis salários-mínimos, estar em um curso da área da saúde e ter algum amigo que já fez UNMMP. Conclusões: A partir desses resultados, sugere-se o desenvolvimento de atividades de prevenção e promoção sobre este tema, especialmente para os alunos e professores dos cursos da área da saúde. Essas intervenções podem ser sobre efeitos adversos desse tipo de uso, bem como sobre estratégias psicossociais de enfrentamento e papéis de gênero socialmente estabelecidos.

\section{PALAVRAS-CHAVE}

Uso não médico de medicamento prescrito, universidades, estudantes.
Received in: Dec/05/2019. Approved in: Jan/05/2020

1 Postgraduate Program in Health Sciences, Federal University of Rio Grande (FURG), Rio Grande, RS, Brazil.

2 Center for Studies on Risk and Health (CERIS), Federal University of Rio Grande (FURG), Rio Grande, RS, Brazil.

3 Postgraduate Program in Public Health, Federal University of Rio Grande (FURG), Rio Grande, RS, Brazil.

4 Postgraduate Program in Psychology, Federal University of Rio Grande (FURG), Rio Grande, RS, Brazil.

Address for correspondence: Lauro Demenech. Av. Itália, km 8 - 96201-900 - Rio Grande, RS, Brazil. E-mail: lauro_demenech@hotmail.com 


\section{INTRODUCTION}

Non-medical use of prescription drugs (NMUPD) is generally defined as the use of controlled medicines without a prescription and/or its use for reasons other than what the medication is intended for or time period other than prescribed ${ }^{1}$. Prescription drugs can be legally purchased and are easier to obtain than most illegal drugs'. NMUPD deserves special attention due to its high potential for abuse and associated health-damaging consequences, which may vary depending on the drugs being used². Advances in strengthening universal health coverage can be observed in many low and middle-income countries, such as Brazil. However, barriers in access, long waiting lines and low-quality attendance persists, which contribute to NMUPD ${ }^{3}$.

Stimulant, anxiolytic, and sedative medications are often used without prescription. This trend is particularly evident among college students 4 . A study conducted in 2013 with individuals aged between 18 and 24 years identified that Brazilian university students reported higher non-medical use of anxiolytics (8.9\% vs. 4.7\%) and amphetamines (10.0\% vs. 2.4\%) than the corresponding Brazilian population5. Recreational (to get "high"), self-medication (relaxing and/or sleeping) and academic purposes (performance improvement) have been pointed as main reasons for NMUPD by undergraduates $s^{6,7}$. Prevalence of NMUPD in this population is rising ${ }^{8}$ and this behavior seems to be more frequent among women ${ }^{9,10}$.

Most of researches on substance use among university students have been dedicated to investigate commonly stigmatized illicit drugs, such as marijuana, crack, cocaine, ecstasy, LSD, and so on. In addition, these investigations have been constrained to convenience samples and/or to healthrelated university population ${ }^{11-14}$. Studies on NMUPD are less frequent, especially in Brazil. Investigations on this topic are mainly produced in high-income countries, ${ }^{6,15-19}$. These researches identified that self-treatment and recreational purposes are the main motivations for NMUPD ${ }^{6}$, and that students that report NMUPD are at greater risk of developing as addiction, negative health consequences due to drug interactions and increased risk of contracting sexually transmitted infections ${ }^{15}$. Furthermore, personality traits may play a role, considering that anxiety sensitivity would be related to non-medical use of anxiolytics and barbiturates, and sensation seeking to stimulants ${ }^{16}$. NMUPD is prevalent among students' social networks, and peers influence seems to have a significant impact on this behavior ${ }^{17-19}$.

Therefore, the aim of this study was to measure lifetime, last-year and last-month prevalence of NMUPD, as well as the characteristics associated to last-month NMUPD among undergraduate students of a university in southern Brazil.

\section{METHODS}

\section{Study design and participants}

This was an observational study with a cross-sectional design. It was conducted at the Federal University of Rio Grande (FURG), a public university with approximately 8,000 undergraduate students. FURG is placed at Rio Grande, Brazil, a municipality that has 200,000 inhabitants, whose economy is mainly based on the port activity (second largest seaport in the country) and the fertilizer industry. This study was approved by the Research Ethics Committee in Health Area of FURG (registration number: 37/2015).

Inclusion criteria were to be 18 years or older, to be a regular undergraduate in any course (presential modality) at Rio Grande campus in the year of 2015. Individuals that had abandoned the course at the time of data collection were considered ineligible.

\section{Sample size and sampling strategy}

It was conducted a clustered systematic sampling based on the relation of all the classes obtained in the university system. Conceptually, a class was defined as the group of people enrolled in the same subject. Classes were used as sample unit and hence design effect were taken into account (deff $=1.5$, parameters: intraclass correlation coefficient $=$ 0.02 , mean cluster size $=20^{10}$ ) .

Two sample size calculations were conducted, one for sample description and another for associated factors. Descriptive sample size calculation showed that it would be necessary 1,290 individuals (parameters: expected prevalence of $10 \%$, margin of error of 2 percentage points, $80 \%$ of Power, $5 \%$ of significance level, plus $10 \%$ for possible losses and refusals and deff of 1.5). Associated factors sample size calculation resulted in 1,811 participants (parameters: exposed/unexposed ratio of 1:4, prevalence ratio $1.8,80 \%$ of Power, $5 \%$ of significance level, plus 10\% for possible losses and refusals, $15 \%$ to control for confounders and deff of 1.5).

Considering an average of 20 students per class ${ }^{10}$, it would be necessary 91 classes $(1,811 \div 20)$. It was added $10 \%$ to the total, to account for the possibility of having individuals enrolled in two or more classes and with ages lower than 18. Therefore, 101 classes were systematically drawn from university system according to a selection interval previously calculated.

\section{Variables and instrument}

A self-administered and confidential questionnaire was used. Lifetime, last-year and last-month prevalence of NMUPD were assessed according to World Health Organization recommendations for studies on drug use with students ${ }^{20}$. Following prescription drugs were included: anxiolytics (diazepam, lorazepam, flunitrazepam and bromazepam), barbiturates (phenobarbital and pentobarbital), and amphetamines (methylphenidate and anfepramone). Use of tobacco, alcohol and illicit drugs 
(marijuana, inhalants, cocaine, crack, mushrooms, ecstasy and LSD), were also assessed with the same method and used as independent variables.

Information on social, economic and behavioral characteristics were also collected as independent variables, namely: sex, age, skin color (self-reported), family income (in Brazilian currency), living situation (with family, alone or with peers), area of study (exact, humanity, health or biological sciences), religious practice, lifetime NMUPD by friends and relatives. A pilot study was conducted to assess interpretation problems, which were further corrected for the final version of the instrument.

\section{Procedures}

Fieldwork was carried out in 2015 during the months of April and June. Professors in charge of chosen subjects were contacted to schedule data collect in their classes. Visits to classes were standardized. Purposes of study were firstly presented, as well as confidentiality measures. Undergraduates were informed that the participation was voluntary and non-participation would not entail any individual losses. Those who agreed to participate signed a free and informed consent form. Afterwards, instruments were answered and deposited directly in a sealed box, aiming increasing confidentiality and hence reliability of responses obtained. Each class was visited at least twice. After two visits, those with more than 10 missing students were visited again. Individuals who were not found at all visits or who refused to participate were considered as losses. All questionnaires data were double-typed by different researchers using Epidata software version 3.1 (Epidata Association, Odense, Denmark), in order to reduce errors in the database.

\section{Data analysis}

Statistical analyses were conducted in Stata IC 13.1 software (Stata Corp., College Station, USA). Univariate analyses were performed to describe sample and to calculate lifetime, last-year and last-month prevalence of NMUPD. Crude and adjusted analyses were carried out through Poisson regression with robust adjustment for variance ${ }^{21}$, according to a four-level hierarchical model of analysis ${ }^{22}$. Outcome used for regression model was last-month of NMUPD, which consisted on use of at least one of the prescription drugs assessed (anxiolytics, barbiturates or amphetamines) at least once 30 days prior the data collect. Estimates were calculated taking deff into account, and level of significance was set at $5 \%$ for two-tailed tests.

\section{RESULTS}

One hundred and one classes were drawn. Eight classes were excluded due to the absence of students enrolled.
Final sample was composed of 93 classes. 2,459 enrollments were counted, of which 721 were ineligible (54 with less than 18 years, 251 enrolled in more than one class and 416 who had canceled enrollment or dropped out at time of the research). This study had 1,738 eligible individuals (19 students per class, on average) and 1,423 undergraduates participated (response rate: $81.9 \%$; losses: 18.1\%; 15.6\% were not found and $2.5 \%$ were refusals).

Table 1 presents participants description according to social, economic and behavioral characteristics. Sample consisted mainly of individuals aged 18 to 25 years (67.5\%), with white skin color (78.6\%), family income between one and six Brazilian minimum wages (63.9\%). Proportion of women was slightly higher (50.7\%) although not statistically significant. One-third of respondents reported living alone or with peers, approximately half of individuals were enrolled on exact sciences-related undergraduate courses and $40 \%$ reported having no religious practice. Last-month use of tobacco, alcohol and illicit drugs were $16.1 \%, 70.6 \%$ and $17.7 \%$, respectively. $10.4 \%$ of individuals reported lifetime NMUPD by a friend, while only $1.7 \%$ reported this type of use by a relative.

Table 1. Description of FURG undergraduate students sample according to demographic, socioeconomic and behavioral variables $(\mathrm{N}=1,423)$ - Rio Grande, Brazil, 2015

\begin{tabular}{|c|c|c|}
\hline Variable & $\mathbf{n}$ & $\%$ \\
\hline \multicolumn{3}{|l|}{$\operatorname{Sex}(N=1,401)$} \\
\hline Female & 711 & 50.7 \\
\hline Male & 690 & 49.3 \\
\hline \multicolumn{3}{|l|}{ Age $(N=1,307)$} \\
\hline 18 to 21 years & 520 & 39.8 \\
\hline 22 to 25 years & 362 & 27.7 \\
\hline 26 to 29 years & 153 & 11.7 \\
\hline 30 years or more & 272 & 20.8 \\
\hline \multicolumn{3}{|l|}{ Skin color $(N=1,410)$} \\
\hline White & 1,109 & 78.6 \\
\hline Black, brown or yellow & 301 & 21.4 \\
\hline \multicolumn{3}{|c|}{ Family income (Brazilian minimum wages) $(\mathrm{N}=1,312)$} \\
\hline Lower than one & 136 & 10.4 \\
\hline Between one and six & 839 & 63.9 \\
\hline Higher than six & 337 & 25.7 \\
\hline \multicolumn{3}{|l|}{ Living situation $(N=1,390)$} \\
\hline Live with relatives & 915 & 65.8 \\
\hline Live alone & 177 & 12.8 \\
\hline Live with peers & 298 & 21.4 \\
\hline \multicolumn{3}{|l|}{ Field of study $(\mathrm{N}=1,414)$} \\
\hline Exact sciences & 725 & 51.3 \\
\hline Humanity sciences & 476 & 33.7 \\
\hline Health sciences & 89 & 6.3 \\
\hline Biological sciences & 124 & 8.7 \\
\hline
\end{tabular}




\begin{tabular}{lcc}
\hline Variable & $\mathbf{n}$ & $\%$ \\
\hline Religious practice $(\mathrm{N}=1,414)$ & 563 & 39.8 \\
Never & 343 & 24.3 \\
Annually & 265 & 18.7 \\
Monthly & 243 & 17.2 \\
Weekly or daily & & \\
Last-month use of tobacco $(\mathrm{N}=1,415)$ & 1,187 & 83.9 \\
No & 228 & 16.1 \\
Yes & & \\
Last-month use of alcohol $(\mathrm{N}=1,388)$ & & \\
No & 408 & 29.4 \\
Yes & 980 & 70.6 \\
Last-month use of illicit drugs $(\mathrm{N}=1,396)$ & & \\
No & 1,149 & 82.3 \\
Yes & 247 & 17.7 \\
Lifetime NMUPD by friend $(\mathrm{N}=1,408)$ & & \\
No & & \\
Yes & 1,261 & 89.6 \\
Lifetime NMUPD by relative $(\mathrm{N}=1,397)$ & 147 & 10.4 \\
No & & \\
Yes & 24 & 98.3 \\
\hline
\end{tabular}

Notes. $N=$ Total of respondents by category; $n=$ Absolute frequency by category; $\%=$ Prevalence; NMUPD $=$ Non-medical use of prescription drugs; FURG = Federal University of Rio Grande.

Table 2 shows that the overall lifetime, last-year and last-month prevalence of NMUPD were $25.2 \%, 13.1 \%$ and $8.5 \%$, respectively. Regarding to type of prescription drug, the anxiolytics and barbiturates presented the highest prevalence in all measures. Prevalence of amphetamines use was slightly lower, a difference that was larger in measure of last-month use.

Table 2. Lifetime, last-year and last-month prevalence of NMUPD among FURG undergraduate students ( $N=1,423)$ - Rio Grande, Brazil, 2015

\begin{tabular}{lccc}
\hline & $\begin{array}{c}\text { Lifetime } \\
\mathbf{\%}(\mathbf{9 5 \%} \mathbf{~ C l})\end{array}$ & $\begin{array}{c}\text { Last-year } \\
\mathbf{\%}(\mathbf{9 5} \% \mathbf{~ C I})\end{array}$ & $\begin{array}{c}\text { Last-month } \\
\mathbf{\%}(\mathbf{9 5} \% \mathbf{~ C l})\end{array}$ \\
\hline NMUPD & $25.2(22.9-27.5)$ & $13.1(11.3-14.9)$ & $8.5(7.1-9.9)$ \\
Types & & & \\
Anxiolytics & $13.1(11.3-14.9)$ & $7.1(5.8-8.4)$ & $4.7(3.6-5.8)$ \\
Barbiturates & $13.6(11.8-15.4)$ & $7.3(5.9-8.6)$ & $4.8(3.7-5.9)$ \\
Amphetamines & $10.0(8.4-11.4)$ & $3.6(2.6-4.6)$ & $1.9(1.2-2.6)$ \\
\hline
\end{tabular}

Notes: $\%=$ Prevalence; $95 \% \mathrm{Cl}=95 \%$ confidence interval; NMUPD $=$ Non-medical use of prescription drugs: * Multiple answers; FURG = Federal University of Rio Grande.

Table 3 exhibits results of crude and adjusted analyses for last-month of NMUPD. In Crude analysis, associated characteristics were: being female, having family income lower than one or higher than six Brazilian minimum wages, studying in a health sciences-related undergraduate course, last-month use of tobacco and illicit drugs and lifetime NMUPD by friends and relatives. After controlling for possible confounders in adjusted analysis, the following variables remained statistically significant: female gender $(P R=1.88$, 95\% Cl 1.33-2.66), family income lower than one Brazilian minimum wages ( $\mathrm{PR}=2.25,95 \% \mathrm{Cl} 1.39-3.66)$ or higher than six ( $P R=2.04,95 \% \mathrm{Cl} 1.36-3.05)$, health sciences-related undergraduate course $(P R=2.04,95 \% \mathrm{Cl} 1.30-3.22)$ and lifetime NMUPD by a friend (PR $=2.63,95 \% \mathrm{Cl} 1.77-3.91)$.

\section{DISCUSSION}

NMUPD in our sample was high when compared to the Brazilian general population. Pooled prevalence of lifetime, last-year and last-month NMUPD in our study were, in this order, three (25.2\% vs. $8.4 \%)$, four $(13.1 \%$ vs. $3.0 \%)$ and seven times higher than rates found in most recent national survey ${ }^{23}$. When comparing specific substances, prevalence of lifetime, last-year and last-month use of amphetamines were, respectively, seven (10.0\% vs. $1.4 \%)$, twelve (3.6\% vs. $0.3 \%)$ and nineteen-fold higher (1.9\% vs. $0.1 \%)^{23}$. Proportion of lifetime and last-year use of anxiolytics were also higher in our sample when compared to Brazilian population (13.1\% vs. $3.9 \%$ and $7.1 \%$ vs. $1.4 \%$, respectively ${ }^{23}$ ). Last-month use of this substance was eleven times higher $\left(4.7 \%\right.$ vs. $0.4 \%{ }^{23}$ ). Barbiturates had the largest differences in comparison to general population. Prevalence of lifetime, last-year and lastmonth use of barbiturates were, in this order, twenty-seven $(13.6 \%$ vs. $0.5 \%)$, seventy-three (7.3\% vs. $0.1 \%)$ and fortyeight (4.8\% vs. $0.1 \%$ ) times higher in our study ${ }^{23}$. Frequency of participants who reported use of amphetamines and anxiolytics in the present survey were similar to results found in other universities samples ${ }^{8,10}$. However, prevalence of barbiturates use in this investigation was higher. Compared to a sample of university students in São Paulo ${ }^{8}$ and to Brazilian university students population ${ }^{10}$, proportion differences are at least five-fold higher in all measures (lifetime, last-year and last-month use of barbiturares). Despite high frequencies yielded by those comparisons, studies conducted in USA $5,15,17,19$ shows that NMUPD among university students in that country are even higher. It is plausible that these results occurred due to the high burden of academic demands, stress and competition of university context. Undergraduates may initiate NMUPD in order to handle such pressures ${ }^{24}$. Especially in the case of amphetamines, its use seems to be related to the competitiveness of academic contex $\mathrm{t}^{25}$ and, as a consequence, to the perception of the need to increase cognitive performance ${ }^{26}$, which might explain high prevalence reported in this sample.

NMUPD was more prevalent among female respondents, an association that has being observed in several other researches on this subject5,10,27. We found only one study that has pointed being male as a risk factor for NMUPD 17. It is plausible that this result occurred due to socially established 
Table 3. Crude and adjusted prevalence ratio for associations between last-month NMUPD and independent variables. Multivariate analysis conducted with four hierarchical levels, through Poisson regression with robust adjustment for variance, accounting for design effect. Sample of FURG undergraduate students ( $\mathrm{N}=1,423)$ - Rio Grande, Brazil. 2015

\begin{tabular}{|c|c|c|c|c|}
\hline Level & Variable & $\%$ & $\begin{array}{c}\text { Crude } \\
\text { PR (95\% Cl) }\end{array}$ & $\begin{array}{c}\text { Adjusted } \\
\text { PR (95\% Cl) }\end{array}$ \\
\hline \multirow[t]{15}{*}{$1^{\text {st }}$} & Sex & & $p=0.002$ & $p<0.001$ \\
\hline & Female & 10.7 & $1.71(1.23-2.37)$ & $1.88(1.33-2.66)$ \\
\hline & Male & 6.3 & 1 & 1 \\
\hline & Age & & $p=0.732$ & $p=0.595$ \\
\hline & 18 to 21 years & 8.6 & 1 & 1 \\
\hline & 22 to 25 years & 7.6 & $0.90(0.60-1.34)$ & $0.98(0.64-1.50)$ \\
\hline & 26 to 29 years & 7.9 & $0.94(0.52-1.73)$ & $1.00(0.50-1.99)$ \\
\hline & 30 years or more & 10,0 & $1,19(0,77-1,85)$ & $1,33(0,85-2,09)$ \\
\hline & Skin color & & $p=0.266$ & $p=0.350$ \\
\hline & White & 9.0 & 1 & 1 \\
\hline & Black, brown or yellow & 7.1 & $0.80(0.54-1.19)$ & $0.81(0.52-1.26)$ \\
\hline & Family income (BMW) & & $p=0.001$ & $p<0.001$ \\
\hline & Lower than one & 13.2 & 2.17 (1.33-3.52) & 2.25 (1.39-3.66) \\
\hline & Between one and six & 6.2 & 1 & 1 \\
\hline & Higher than six & 11.6 & 1.89 (1.26-2.82) & $2.04(1.36-3.05)$ \\
\hline \multirow[t]{14}{*}{$2^{\text {nd }}$} & Living situation & & $p=0.120$ & $p=0.064$ \\
\hline & Live with relatives & 7.9 & 1 & 1 \\
\hline & Live alone & 12.5 & 1.59 (0.99-2.53) & $1.40(0.84-2.33)$ \\
\hline & Live with peers & 8.8 & $1.10(0.70-1.73)$ & $0.79(0.45-1.38)$ \\
\hline & Field of study & & $p<0.001$ & $p=0.003$ \\
\hline & Exact sciences & 7.5 & 1 & 1 \\
\hline & Humanity sciences & 8.6 & $1.12(0.75-1.69)$ & $1.07(0.68-1.68)$ \\
\hline & Health sciences & 18.0 & $2.35(1.67-3.31)$ & $2.04(1.30-3.22)$ \\
\hline & Biological sciences & 8.1 & $1.06(0.68-1.66)$ & $0.97(0.58-1.61)$ \\
\hline & Religious practice & & $p=0.753$ & $p=0.884$ \\
\hline & Never & 8.4 & 1 & 1 \\
\hline & Annually & 8.5 & $1.01(0.66-1.55)$ & $0.86(0.55-1.35)$ \\
\hline & Monthly & 10.1 & $1.20(0.76-1.88)$ & $0.87(0.54-1.43)$ \\
\hline & Weekly or daily & 7.5 & $0.89(0.52-1.53)$ & $0.87(0.52-1.56)$ \\
\hline \multirow[t]{9}{*}{$3^{\text {rd }}$} & Last-month use of tobacco & & $p<0.001$ & $p=0.062$ \\
\hline & No & 7.3 & 1 & 1 \\
\hline & Yes & 15.0 & $2.03(1.40-2.95)$ & $1.53(0.98-2.41)$ \\
\hline & Last-month use of alcohol & & $p=0.067$ & $p=0.161$ \\
\hline & No & 6.2 & 1 & 1 \\
\hline & Yes & 9.4 & $1.51(0.97-2.34)$ & $1.44(0.86-2.38)$ \\
\hline & Last-month use of illicit drugs & & $p=0.025$ & $p=0.057$ \\
\hline & No & 7.6 & 1 & 1 \\
\hline & Yes & 12.2 & $1.60(1.06-2.41)$ & $1.52(0.98-2.35)$ \\
\hline \multirow[t]{6}{*}{$4^{\text {th }}$} & Lifetime NMUPD by friend & & $p<0.001$ & $p<0.001$ \\
\hline & No & 7.3 & 1 & 1 \\
\hline & Yes & 20.3 & $2.78(1.90-4.07)$ & $2.63(1.77-3.91)$ \\
\hline & Lifetime NMUPD by relative & & $p=0.029$ & $p=0.545$ \\
\hline & No & 8.3 & 1 & 1 \\
\hline & Yes & 20.8 & $2.47(1.09-5.54)$ & $1.38(0.49-3.88)$ \\
\hline
\end{tabular}

Notes. $\%$ = Frequency of last-month NMUPD by exposure categories; PR = Prevalence ratio; $95 \% \mathrm{Cl}=95 \%$ confidence interval; BMW = Brazilian minimum wages; NMUPD = Non-medical use of prescription drugs; FURG = Federal University of Rio Grande. 
gender roles. Women suffer greater social pressure for an ideal body, which may lead to an increase use of amphetamines for anorexigenic purposes ${ }^{28}$. Furthermore, it is possible that use of anxiolytics and barbiturates serves to cope with anxiety stemming from stereotypes that burden women with the need of a double-shift workload. Despite pursuing a career in labor market, women are still considered as main responsible for home and family-related tasks, increasing probability of developing anxiety symptoms ${ }^{29}$. However, it should be noted that females are more predisposed to develop anxiety disorders ${ }^{30}$ and insomnia ${ }^{31}$, which might have contributed to higher prevalence of NMUPD as a self-treatment strategy.

The results showed an association between family income and NMUPD. Both individuals with a family income below one and above six Brazilian minimum wages were twice as likely to have had this behavior. This may have occurred due to different mechanisms. Among those with lower income, it is possible that NMUPD serves as a substitute for medical and/or psychological care, due to both the barriers in access to public services and lack of money to hire private professionals ${ }^{32,33}$. Among participants with higher family income, high prevalence of NMUPD may be a result of easy access to prescription drugs. One possible pathway is through social capital, in terms of resources that flow and emerge through social network. Thus, higher income families may have effortless access to professionals qualified to prescribe drugs (such as physicians) and hence to these medications ${ }^{34}$, even though not necessarily for the purpose to which these drugs are intended for.

Participants who reported lifetime NMUPD by friends had $163 \%$ increased probability to exhibit the same behavior. It is noteworthy that this was the strongest association identified, highlighting the importance of social relations for this outcome. This may have occurred due to peer influence and social learning. First, peer influence can produce social pressure, generating behaviors targeting acceptance and belonging, especially in cases of amphetamine use to enhance academic performance ${ }^{35}$ and recreational use of prescription drugs to get "high"36. Secondly, social learning encompasses the phenomenon of how individuals learn to deal with life situations from the observed examples ${ }^{37}$. It is possible that respondents have learned, through modeling behaviors from their peers, to cope with problems with NMUPD ${ }^{19}$. Individuals who struggle with symptoms similar to those faced by friends or relatives (such as difficulties to sleep or to stay awake, getting over the end of a relationship and so on) may also adopt their same responses (such as NMUPD).

NMUPD was more frequent among health sciences undergraduate students, which is in line with results of researches on this topic ${ }^{38-40}$. In a Brazilian study, it was identified that NMUPD among health sciences undergraduates occurred mainly due to their knowledge and easy access to those prescription drugs ${ }^{40}$. It is plausible to argue that this expertise combined with easy access to prescription drugs $s^{39}$ might have contributed to higher prevalence of NMUPD among this subgroup when compared to undergraduates from other areas. It is expected that receiving training about prescription drugs would contribute to a healthy and rational use of these remedies. Actually, perhaps it is exactly what predisposes them to an inappropriate use $\mathrm{e}^{40}$.

Religious practice has been consistently described as a protective factor to licit and illicit drug use $\mathrm{e}^{41-43}$. However, we did not found any statistical association of this variable with NMUPD. This is an intriguing result, which might shed a light to an important underlying issue. Religion exerts a protective influence on widely known harmful and stigmatized substances (such as alcohol, tobacco, marijuana, crack, cocaine and so on) ${ }^{41-43}$. Absence of a protective role of religion on NMUPD may reflect general underestimation of its potential for abuse and health threatening consequences.

Due to the nature of epidemiologic surveys, this research has some limitations. First, it is not possible to make causal inferences because both dependent and independent variables were collected at the same time, not allowing establishing temporal relationship. Therefore, associations between outcome and exposures are susceptible to reverse causality bias and should be interpreted with caution. Second, it is possible that prevalence of NMUPD was underreported due to occurrence of false response bias and to exclusion of individuals that dropped out at the time of data collection. Third, psychiatric comorbidities were not assessed, which could be a possible source of confounding of investigated outcome. Lastly, non-medical use of opioids were not assessed. Considering that in the most recent Brazilian national survey, this was one of the most reported prescription drugs misused ${ }^{23}$, prevalence of NMUPD in this sample could have been even higher.

Notwithstanding, this study also have some strengths. Cross-sectional design was adequate to answer research questions raised in this study. In addition, most of surveys about this topic has been conducted only with health sciences-related undergraduate courses and are largely restricted to convenience samples. In our study, clustered systematic sampling strategy provided a representative sample of university, which in turn allowed comparability of NMUPD between undergraduates from different areas. Multivariate analysis also played an important role, controlling simultaneously several possible confounders and hence contributing to results that are more precise.

\section{CONCLUSIONS}

Present study showed that NMUPD in this sample was high in all of its measures when compared to Brazilian general population. Anxiolytics and barbiturates had higher 
prevalence, being followed by amphetamines. Variables independently associated with last-month NMUPD were being women, having family income lower than one or higher than six Brazilian minimum wages, lifetime NMUPD by a friend and being enrolled in a health sciences-related undergraduate course. Our results also suggest that harmful effects of NMUPD may be underestimated in this population. We recommend preventive actions alerting about health damaging consequences of NMUPD and its potential for abuse targeting especially health sciences-related undergraduate students and professors. These interventions could also address other topics, for instance: psychosocial coping strategies to enhance undergraduates' abilities to handle everyday-life problems; and social established gender roles, focusing on how to mitigate its' effects on women's health. In addition, strengthening student assistance services that guarantee access to on-campus social and health care counseling able to referral students to health system may reduce NMUPD in this population.

\section{INDIVIDUAL CONTRIBUTIONS}

Lauro Miranda Demenech, Samuel de Carvalho Dumith and Lucas Neiva-Silva - Contributed in the conception and design of the study, in data analysis and interpretation, and in drafting and revising the paper.

Alessandro S. Dytz and Fernanda Fontes - Contributed in data analysis and interpretation, and in the drafting of the paper. All authors approved the final version.

\section{CONFLICTS OF INTEREST}

The authors report no conflicts of interest.

\section{ACKNOWLEDGEMENTS}

First author received a scholarship from CAPES (Coordenação de Aperfeiçoamento de Pessoal de Nível Superior) to conduct this study. Second author is a research productivity fellow at CNPq (Conselho Nacional de Desenvolvimento Científico e Tecnológico).

\section{REFERENCES}

1. Martins SS, Ghandour LA. Nonmedical use of prescription drugs in adolescents and young adults: not just a Western phenomenon. World Psychiatry. 2017;16(1):102-4.

2. Zacny J, Bigelow G, Compton P, Foley K, Iguchi M, Sannerud C. College on Problems of Drug Dependence taskforce on prescription opioid non-medical use and abuse: position statement. Drug Alcohol Depend. 2003;69(3):215-32.
3. Arrais PSD, Fernandes MEP, Pizzol TSD, Ramos LR, Mengue SS, Luiza VL, et al. Prevalence of self-medication in Brazil and associated factors. Rev Saude Publ. 2016;50(Suppl 2):11.

4. McCabe SE, Boyd CJ, Teter CJ. Subtypes of nonmedical prescription drug misuse. Drug Alcohol Depend. 2009;102(1-3):63-70.

5. Eckschmidt F, Andrade AG, Oliveira LG. Comparison of drug use between Brazilian and American college students and young Brazilian general population. J Bras Psiquiatr. 2013;62(3):199-207.

6. Messina BG, Dutta NM, Silvestri MM, Diulio AR, Garza KB, Murphy JG, et al. Modeling motivations for non-medical use of prescription drugs. Addict Behav. 2016;52:46-51.

7. Arria AM, Caldeira KM, Vincent KB, O'Grady KE, Cimini MD, Geisner IM, et al. Do college students improve their grades by using prescription stimulants nonmedically? Addict Behav. 2017;65:245-9.

8. Wagner GA, Oliveira LG, Barroso LP, Nishimura R, Ishihara LM, Stempliuk VA, et al. Drug use in college students: a 13-year trend. Rev Saúde Pública. 2012;46(3):497-504.

9. Wagner GA, Stempliuk VA, Zilberman ML, Barroso LP, Andrade AG. Alcohol and drug use among university students: gender differences. Braz J Psychiatry. 2007;29(2):123-9.

10. Andrade AG, Duarte PCAV, Oliveira LG. I Levantamento Nacional Sobre o Uso de Álcool, Tabaco e Outras Drogas Entre Universitários das 27 Capitais Brasileiras. São Paulo: Secretaria Nacional de Políticas sobre Drogas (SENAD); 2010.

11. Portugal FB, Souza RS, Bualz V, Siqueira MM. Use of drugs by Pharmacy students at the Federal University in Espírito Santo. J Bras Psiquiatr. 2008;57(2):127-32.

12. Lucas ACS, Parente RCP, Picanço NS, Conceição DA, Costa KRC, Magalhães IRS, et al. Use of psychoactive drugs by health sciences undergraduate students at the Federal University in Amazonas, Brazil. Cad Saúde Pública. 2006;22(3):663-71.

13. Oliveira LG, Barroso LP, Wagner GA, Ponce JC, Malbergier A, Stempliuk VA, et al. Drug consumption among medical students in São Paulo, Brazil: influences of gender and academic year. Rev Bras Psiquiatr. 2009;31(3).

14. Tockus D, Gonçalves PS. Detection of drugs abuse among Medicine students in a private university. J Bras Psiquiatr. 2008;57(3):184-7.

15. Benotsch EG, Koester S, Luckman D, Martin AM, Cejka A. Non-medical use of prescription drugs and sexual risk behavior in young adults. Addict Behav. 2011;36(1-2):152-5.

16. Chinneck A, Thompson K, Mahu IT, Davis-MacNevin P, Dobson K, Stewart SH. Personality and prescription drug use/misuse among first year undergraduates. Addict Behav. 2018;87:122-30

17. Kilmer JR, Geisner IM, Gasser ML, Lindgren KP. Normative perceptions of non-medical stimulant use: associations with actual use and hazardous drinking. Addict Behav. 2015:42:51-6

18. Meisel MK, Goodie AS. Predicting prescription drug misuse in college students' social networks. Addict Behav. 2015;45:110-2.

19. Peralta RL, Steele JL. Nonmedical prescription drug use among US college students at a Midwest university: a partial test of social learning theory. Subst Use Misuse. 2010;45(6):865-87.

20. World Health Organization. A methodology for student drug-use surveys. Geneva: WHO; 1980.

21. Barros AJD, Hirakata VN. Alternatives for logistic regression in cross-sectional studies: an empirical comparison of models that directly estimate the prevalence ratio. BMC Med Res Methodol. 2003;3:21.

22. Victora $\mathrm{CG}$, Huttly SR, Fuchs SC, Olinto MT. The role of conceptual frameworks in epidemiological analysis: a hierarchical approach. Int J Epidemiol. 1997;26(1):224-7.

23. Bastos FIPM, Vasconcellos MTL, Boni RBD, Reis NB, Coutinho CFS. III Levantamento Nacional sobre 0 uso de drogas pela população Brasileira. Rio de Janeiro: Fiocruz/ICICT; 2017.

24. Betancourt J, Rios JL, Pagan I, Fabian C, Gonzalez AM, Cruz SY, et al. Non-medical use of prescription drugs and its association with socio-demographic characteristics, dietary pattern, and perceived academic load and stress in college students in Puerto Rico. P R Health Sci J. 2013;32(2):89-94.

25. McCabe SE, Knight JR, Teter CJ, Wechsler H. Non-medical use of prescription stimulants among US college students: prevalence and correlates from a national survey. Addiction. 2005;100(1):96-106.

26. Singh I, Bard I, Jackson J. Robust resilience and substantial interest: a survey of pharmacological cognitive enhancement among university students in the UK and Ireland. PLoS One. 2014;9(10):e105969. 
27. Lucena V, Ruiz-Olivares R, Pino MJ, Herruzo J. Consumo de al cohol, tabaco y psicofármacos en jóvenes universitarios y no universitarios. Psicol Conduct. 2013;21(1):123-36.

28. Melo CM, Oliveira DR. The use of apetite inhibitors by women: an insight based on the gender perspective. Ciênc Saúde Coletiva. 2011;16(5):2523-32.

29. Souza ARL, Opaleye ES, Noto AR. Contexts and patterns of undue use benzodiazepine among women. Ciênc Saúde Coletiva. 2013;18(4):1131-40.

30. Baxter AJ, Scott KM, Vos T, Whiteford HA. Global prevalence of anxiety disorders: a systematic review and meta-regression. Psychol Med. 2013;43(5):897-910.

31. Bos SC, Macedo AF. Literature review on Insomnia (2010-2016). Biol Rhythm Res. 2018:50(8):1-70

32. Pagan JA, Ross S, Yau J, Polsky D. Self-medication and health insurance coverage in Mexico. Health Policy. 2006;75(2):170-7.

33. Shaghaghi A, Asadi M, Allahverdipour H. Predictors of Self-Medication Behavior: A Systematic Review. Iran J Public Health. 2014;43(2):136-46.

34. Solar 0, Irwin A. A conceptual framework for action on the social determinants of health. Geneva: World Health Organization; 2010.

35. White BP, Becker-Blease KA, Grace-Bishop K. Stimulant medication use, misuse, and abuse in an undergraduate and graduate student sample. J Am Coll Health. 2006;54(5):261-8
36. Rigg KK, Ibanez GE. Motivations for non-medical prescription drug use: a mixed methods analysis. J Subst Abuse Treat. 2010;39(3):236-47.

37. Bandura A. Social learning theory. 1st ed. Englewood Cliffs, New Jersey: Prentice-Hall; 1976. 256p.

38. Paim RSP, Lunelli RP, Zanchett K, Menon P, Costa S, Giachelin T. Automedicação: uma síntese das publicações nacionais. Rev Contexto Saúde. 2016;16(30):47-54.

39. Jesus APGAS, Yoshida NCP, P. FJGA. Prevalence self-medicated academic pharmacy, medicine, nursing and dentistry. Estudos. 2013;40(2):151-64.

40. Aquino DS, Barros JAC, Silva MDPA. Self-medication and health academic staff. Ciênc Saúde Coletiva. 2010;15(5):2533-8.

41. Gomes FC, de Andrade AG, Izbicki R, Moreira Almeida A, Oliveira LG. Religion as a protective factor against drug use among Brazilian university students: a national survey. Braz J Psychiatry. 2013;35(1):29-37.

42. Kelly E, Polanin JR, Jang SJ, Johnson BR. Religion, Deliquency, and Drug Use: A MetaAnalysis. Crim Justice Rev. 2015;40(4):19.

43. Yeung JW, Chan YC, Lee BL. Youth religiosity and substance use: a meta-analysis from 1995 to 2007. Psychol Rep. 2009;105(1):255-66. 